\title{
Why we need to talk about lifelong learning and intercultural universities
}

\author{
Lorena Sanchez Tyson* and Valerie Watson Vega - UCL Institute \\ of Education, UK
}

\begin{abstract}
This article explores whether and how contemporary discourses in lifelong learning (LLL) can support intercultural universities in Latin America. Since the late twentieth century, LLL has primarily been seen through a Eurocentric lens, with a strong focus on the development of skills for knowledge-based economies and societies. As this discourse has been promoted and adopted by so-called developing countries, the focus has shifted from an identified need for continuous learning in a global society to mainly targeting the promotion of basic education, as is evidenced by the United Nations Sustainable Development Goals. In this context, we have identified a need for further discussion and research on intercultural universities, many of which are becoming increasingly vulnerable in current neoliberal times. This article looks at two intercultural universities in Mexico and Ecuador and suggests that a more indigenized approach to LLL could provide a stronger sense of ownership and participation in decision-making. Thus, LLL can be an ally for a new and decolonized conceptual framework that further legitimizes intercultural universities and provides a long-term strategy for the future.
\end{abstract}

Keywords: intercultural education, higher education, decolonizing knowledge, Latin America, lifelong learning

\section{Introduction}

This article focuses on the need for an intercultural, context-based lifelong learning (LLL) agenda for Latin American (LA) countries. This reframing draws from the foundations of LLL as a concept, looking back at the social problems that it intended to address and how it can be linked to the needs of countries that have wider concerns than global competitiveness (Preece, 2009). In this context, intercultural universities have been identified as vulnerable institutions that are at risk of being undermined by mainstream Western knowledge and standards (the term Western referring to, in a broad sense, Westernized knowledge and universities). This article aims to open a discussion on the argument that intercultural universities would benefit from a new direction in LLL that stems not just from academia but from what Robinson-Pant (2001: 324) calls 'bottomup grassroots social movements', particularly with regard to stakeholder ownership and decision-making. Furthermore, it suggests that LLL should move towards a more contextualized and hybrid approach to development that tackles problems by seeking solutions that build on LLL systems that emerge from local values.

This article takes an exploratory and theoretical approach and does not present first-hand empirical data. The first section provides an overview of LLL and explores 
how it can be conceptualized in terms of the global North-South divide. This is followed by an overview of three key components of the LA context: indigeneity, interculturality and the history of higher education (HE) in the region. This historical and theoretical overview provides a foundation to explore the similarities, differences and linkages between two intercultural universities in Mexico and Ecuador by drawing from emerging research and with a particular emphasis on governance and indigenous representation in decision-making. Finally, the article suggests that the LLL discourse can be a strong ally for a renewed conceptual and policy framework as seen through a decolonial lens, which further legitimizes these institutions and provides a long-term strategy for the future.

\section{About lifelong learning}

The underpinning principles that have shaped contemporary LLL theories and practices are wide ranging and vary from region to region. Following several key United Nations Educational, Scientific and Cultural Organization (UNESCO) publications from the 1970s onwards (Delors, 1996; Faure et al., 1972), LLL emerged as a cornerstone of most education and training systems in the twenty-first century, with the notion of the learning or knowledge society at its core (Schuetze, 2005).

Europe rapidly became a leading voice in the international race to build a formalized LLL strategy. Through the Lisbon Strategy action plan, Europe focused the bulk of its economic goals on knowledge and employability (Robertson, 2008). A Memorandum on Lifelong Learning (Commission of the European Communities, 2000) was published with the intention of opening a discussion between member states and candidate states on LLL (Nuissl and Przybylska, 2016). Similarly, with the document Adult Learning: It is never too late to learn (Commission of the European Communities, 2006) the European Commission emphasized the importance of building efficient educational systems of quality and the need to implement validation and recognition procedures for formal and informal learning. The document suggested that competitiveness, demographic change and social inclusion were the three main challenges to achieving these goals, and that learning opportunities should be expanded 'in relation to linguistic, social and cultural integration' by 'developing appropriate and effective teaching and promoting more intercultural learning' (ibid.: 10).

The global shift whereby learning was increasingly defined as a lifelong and lifewide process brought with it several implications. A corollary of this shift was that LLL quickly became interpreted as a strategy for continuous development (focused on the right to develop with a humanistic approach) and a way of capitalizing human resources (human capital approach), focused more on 'competitiveness' and less on 'social inclusion' (Preece, 2009; Vargas, 2017).

The human capital approach assumes that an investment in knowledge (education and training) will yield economic advantages for individuals and the state, as skilled employees can potentially generate more profit (Lauder, 2011; Baker, 2009). This new relationship between education and economic development has continually affected global educational systems and is largely 'shaped by wider geo-strategic political and economic interests' (Robertson, 2008: 1), particularly those stemming from influential Northern countries. Individual socioeconomic mobility became, in many cases, inextricably linked to a country's overall economic growth, thereby propelling policy agendas that were mainly driven by fostering economic competitiveness (Preece, 2009; Vargas, 2017). The idea that education within the new and complex knowledge society needed to adapt and keep abreast of ever-changing social and economic shifts (Nuissl 
and Przybylska, 2016) was not exclusively promoted by the European Commission, but also by other international governmental organizations (IGOs) by way of prominent reports designed to influence the reformation of educational policies and systems and align them with the concept of a knowledge society and economy. One example of this was how the Organisation for Economic Co-operation and Development (OECD) embedded LLL in various documents such as 'Lifelong Learning for All' (OECD, 1996) and more recently in the '21st Century Skills and Competences for New Millennium Learners in OECD Countries' (Ananiadou and Claro, 2009), bringing economic growth, global competitiveness, qualifications and training into the same arena. One key example of the impact these policies had on the educational sector was the rapid growth of for-profit universities in LA beginning in the 1980s (Benavides et al., 2015). Initially proposed by the World Bank, these institutions were seen as a way of satisfying the demand for skills without compromising public spending (Balán, 2013; Torres and Schugurensky, 2002).

This reconceptualization and reconstruction of learning continues to be triggered by the phenomenon of globalization (OECD, 2009). In this scenario, international policymakers have become increasingly interested in identifying and imitating international 'best practices' (Portnoi, 2016; Steiner-Khamsi, 2016; Raffe, 2011; Raffe and Spours, 2007); in doing so, these 'best practices' from 'successful' countries are seen as something transferable to other contexts with the expectation that they will produce similarly 'successful' results (Raffe, 2011).

Vargas (2017: 1) suggests that there is an emerging 'set of globally converging discourses' concerning LLL embedded in human capital formation and the global labour market. This conceptual narrowing means that the many educational dimensions, interests and needs of different countries (particularly those considered to be culturally, linguistically, and ethnically diverse - like many in the global South) are at risk of being undermined. In culturally and economically diverse contexts, education for the purpose of economic performance, productivity and competitiveness are prioritized and pushed forward as a means to participate on the global stage. Thus, the interplay between the local and the global discourse on LLL has uncovered certain tensions. Torres (2004: 86) argues there are dual standards for the understanding and implementation of LLL discourses worldwide: while in Northern countries LLL is understood as 'promoting economic competitiveness, employability and citizenship', the focus is placed on basic education provision in Southern countries, thereby neglecting the heterogeneous educational needs within the region and revealing 'ongoing and unequal power relations' (Preece, 2009: 588). As such, this difference makes it difficult to compare the results of LLL initiatives in both regions.

This Northern transplantation of the LLL discourse is occurring at a time when Southern countries are grappling with what learning means in a postcolonial world that is still heavily influenced by Northern conceptions. At the same time, these countries are arguably under neocolonial control through conditional aid and imposed concepts of development (Bhambra et al., 2018). This neo-colonialism not only influences educational institutions in the South, but it also underpins exploitation of human and natural resources in the name of capitalist growth and external agendas that maintain these countries in a state of perpetual development (Preece, 2009). This affects indigenous peoples directly, as their culture and traditions are in most cases circumscribed to a certain territory (Diamantino, 2017).

Authors such as Torres $(2004)$ and Preece $(2009,2011)$ have addressed the need to challenge the concept of LLL from the perspective of the South in order to widen the debate, thereby helping to build what they consider to be a more global vision for LLL. 
This new direction for LLL needs to acknowledge the 'present realities of globalisation and development' while at the same time recognizing the underpinning 'influence[s] of pre-colonial, colonial and postcolonial experiences' (Preece, 2011: xiv). Furthermore, Preece (2009: 596) makes reference to potential processes of 'indigenisation' and facilitation of ownership of the LLL agenda by drawing from examples within the African context (for example, linking LLL with the African concept of ubuntu or humanness) that emphasize the multidimensional and sectoral qualities of LLL. By shedding light on LA intercultural universities and considering them as educationally innovative (Mato, 2014), we aim to inform and enhance the global LLL agenda.

\section{About indigeneity and interculturality}

The term indigenous lacks a universal definition, making it difficult to determine who (and if) someone belongs to an indigenous community (García, 2008). Broadly speaking, indigenous peoples retain distinct cultural, political and social features within wider dominant societies (Broch Hansen et al., 2017). Some common characteristics of indigenous peoples are distinct heritage, languages and traditions, a self-identification of being indigenous or tribal, and strong links to a territory, to name a few (VásquezHuamán et al., 2009; Arteaga and Glewwe, 2014; Flores and Díaz-Romero, 2008). Similarly, the concept of interculturality is multidimensional in nature and is distinctly shaped by the struggle of indigenous peoples for self-determination, legal rights and the preservation of their own cultures and languages against different processes of domination (Ahuja et al., 2004; Sanchez Tyson, 2017). Martín-Díaz (2017: 85) argues that the concept of interculturality has both a theoretical and political dimension and represents an 'epistemic transformation' that has the potential to transcend the limitations of multiculturalism as a conceptual framework and encourage coexistence and a continuous exchange of ideas between different cultures.

Across all regions of the world, indigenous peoples are confronted with many intersecting variables such as poverty and marginalization, which are often made more acute by other factors such as race, ethnicity, gender and location (Hanemann, 2005). Additionally, many indigenous communities live in remote areas that often prevent them from accessing basic services such as water, electricity, healthcare or education (Salinas de Dosch, 2012).

This fundamental issue of access to relevant education for indigenous peoples in LA is longstanding and permeates all levels of education. Historically, indigenous education has been characterized by territorial and intellectual marginalization: first, formalized educational provision was scarce until the mid-twentieth century, and even then its function was primarily to 'integrate the indigenous population into "mainstream" society' (Schmelkes, 2011: 91). National educational curricula were constructed using Spanish and Portuguese as the national languages of instruction and with the aim of providing indigenous peoples with the tools and skills deemed necessary to 'fit in' with the wider society (García, 2008). This assimilationist agenda continued for decades until the 1990s, when different ministries of education in LA began adopting a more intercultural perspective with the objective of adapting and redesigning national curricula to better suit different indigenous contexts.

Despite these efforts, many indigenous peoples, Afro-descendants and AfroCaribbeans continue to face severely restricted access to education in LA, particularly in HE (Hopenhayn and Bello 2001). According to Guilherme and Dietz (2017), $\mathrm{HE}$ access for indigenous students remains extremely limited, with an estimated enrolment of only 1 or 2 per cent of all students. In addition, universities remain highly 
centralized, Westernized in their curricula and primarily found in urban environments. Oyarzún et al. (2017: 852) refer to a fundamental 'double exclusion' of indigenous groups in LA with regards to access to HE: first, there have been and continue to be low levels of institutional access for indigenous peoples (ranging from participation in HE to participation in the formal economy), and second, there is a conspicuous lack of awareness and acknowledgement of distinct traditions (both cultural and epistemological) within contemporary HE curricula (Mato, 2014).

There have been several key international efforts to reduce the educational disparities and ensure greater access to pertinent educational opportunities for indigenous peoples. For example, the United Nations (UN) Declaration of the Rights of Indigenous People specified in Article 14 that indigenous peoples have the right to create and manage their educational systems and institutions, and that the methods and contents of education should be consonant with their own cultures and languages (Department of Economic and Social Affairs, 2009). Similarly, by 2014, 14 LA countries ratified their commitment to the International Labour Organization's (ILO) Convention on Indigenous and Tribal Peoples (C169). This document states, among other things, that all education and training development and provision should be developed and implemented in direct cooperation with indigenous peoples (ILO, 1989). Article 26 explains that the subscribed countries must guarantee access to quality education for indigenous peoples at all levels. Article 27 explicitly states that indigenous education must 'incorporate [indigenous] histories, their knowledge and technologies, their value systems and their further social, economic and cultural aspirations'. The same article explains that governments should provide the resources needed for these educational projects, and that intercultural educational institutions are required to achieve minimum standards set by the national educational quality assurance office.

Mato (2014) emphasizes a contradiction within Article 27, pointing out that on one hand this section empowers and recognizes indigenous communities in their educational processes, but then quickly limits their independence to governmental standards. Consequently, Mato (ibid.: 23) argues that this section summarizes the 'nucleus' of conflicts with intercultural universities, which will be addressed in the following section.

\section{Universities in Latin America}

From the outset, universities in LA were not designed or implemented to satisfy local or regional needs, but rather to facilitate the transplantation of European education and beliefs in the colonies (De Carvalho and Flórez-Flórez, 2014). These institutions first emerged under Spanish colonial rule in an attempt to replicate the type of education offered in Spain for the criollos (Spanish descendants born in America) and the elite (Balán, 2013; De Wit et al., 2005). The Spanish colonial system made strict distinctions between the population concerning race and origin, even distinguishing amongst the Spaniards born in Spain as 'superior' to those born in the colonies (the criollos). Following independence, many LA countries still remained under heavy colonial influences. Educational policies in newly independent states sought to 'create a national narrative that glossed over differences' and implemented educational policies 'openly aimed at homogenising national imaginaries' (Mato, 2016: 214).

The impact of globalization on educational systems in LA has proved to be a challenge given that many nation states are still struggling between unsatisfied internal cultural demands, external pressures and rising demand for HE (Gacel-Ávila, 2011). As a result, many LA countries encouraged the legalization and establishment of for- 
profit universities in the 1980s and 1990s (Ferreira et al., 2013; Torres and Schugurensky, 2002). The primary rationale was to allow the demand for HE to self-regulate in the market and thus be satisfied by for-profit universities. At the same time, it was thought that countries could prioritize public spending on basic education (Benavides, et al., 2015). However, as De Wit et al. (2005: 53) argued, this was 'a recipe for mounting inequalities in already unequal societies'.

Cuenca (2015) describes an inverse correlation between the expansion in the number of universities and their diminishing quality. The lack of state control on educational provision meant that the for-profit university system continued to perpetuate the pre-existing elitism of HE systems: wealthier (and often non-indigenous) students continued to be the ones with access to higher quality educational services from the most prestigious universities, and thus kept reaping the most benefit from them (Benavides et al., 2015; Martins, 2013; Rodríguez Ponce, 2012).

Around the world, contemporary universities are broadly known for being institutions where knowledge is generated and disseminated through research and scholarship (Denman, 2005). Mato (2012) argued that the attributes of Western universities have been universalized by centuries of educational domination from a handful of countries. In this sense, universities are often pressured to produce scientific knowledge - in the Western understanding of science as a tangible product - and indigenous knowledge is left to be dealt with according to the legal frameworks of each country. This creates a paradox, since national histories have previously condemned indigenous knowledge as 'witchcraft' and a mystical way of understanding the world (Mato, 2012; Watson Vega, 2017). As such, the policies and practices dominant in Northern universities have long been at odds with the educational aspirations of indigenous peoples and have promoted streamlined integration policies aimed at constructing a homogeneous social imaginary without acknowledging or incorporating those 'histories, knowledges, and languages of indigenous peoples into the university tradition' (Martín-Díaz, 2017: 77).

Driven by indigenous movements and following the commitment with ILO Convention 169 (1989), countries such as Mexico, Ecuador, Peru, Bolivia and Colombia started supporting and encouraging the opening of intercultural universities in the early 2000s (Mato, 2012). There are many different examples of how these institutions are operating at present. Owing to the limited scope of this article, there will not be an exhaustive overview of all intercultural universities, as these are heterogeneous and differ in ideological views and fundamental aims depending on the context (Erdösová, 2015). Rather, we have selected two contrasting examples of intercultural universities in Mexico and Ecuador to explore whether and how LLL could support these institutions and others like them.

\section{Intercultural universities: The cases of Mexico and Ecuador}

The two universities that this article explores are the Universidad Veracruzana Intercultural (UVI) and the Intercultural University Amawtay Wasi (IUAW). These two universities exemplify, on a small scale, the types of changes that are happening in HE in the region and how LA countries are attempting to respond to the need for a new decolonizing conceptual framework in education that encourages horizontal, symmetrical and reciprocal relationships (Briones, 2008). We argue that these institutions share key similarities in that they are both culturally and linguistically diverse post-colonial countries where neoliberal policies have affected HE (Mato, 
2014). Furthermore, they share a history of indigenous marginalization in education, which has arguably led to similar challenges with regard to intercultural universities (ibid.). In this context, while the UVI has managed to establish an ongoing cooperation with different indigenous groups in the region, the IUAW was unable to meet national accreditation standards and was shut down in 2013, hindering the efforts of local indigenous groups who advocated for keeping the university open (Torres, 2019). The following sections will address the particularities of each case.

\section{Universidad Veracruzana Intercultural (Mexico)}

In Mexico, between 11 and 16 per cent of the population is indigenous, which represents approximately 10 million people (Mato, 2014). Out of these, it is estimated that less than 3 per cent enrol in HE (Schmelkes, 2009). Although the topic of relevant and self-determined educational access for indigenous peoples was underscored by the Zapatista movement in the mid-1990s, the first intercultural university did not open until 2003 (Erdösová, 2015). A branch of the Ministry of Education called the General Coordination for Intercultural and Bilingual Education played a key role in helping to establish these universities in partnership with local indigenous organizations and other regional educational institutions.

Currently, there are 12 federally backed intercultural universities in Mexico serving approximately 7,000 students (UNESCO, 2015). Five other autonomous intercultural universities have also been recognized by the government (Dietz and Mateos Cortés, 2016). In addition, there are a number of independent intercultural HE institutions that operate without any support from the government, including the Universidad de la Tierra and the Universidad Campesina e Indígena en Red (Mateos Cortés and Dietz, 2015).

These universities all share similar characteristics in that they do not follow a fixed approach to the curricula or activities; rather, they define these in accordance with the identified needs of the local region (Schmelkes, 2009). The UVI was established in 2005 as a pioneering initiative linked to an already established university. The UVI focuses on students from indigenous regions of the country who 'have been excluded from formal higher education' and who have only recently had access to basic and upper secondary educational pathways (Mateos Cortés and Dietz, 2015: 127). More recently, there have been many studies aimed at demonstrating the potential of the intercultural project at UVI (Dietz and Mateos Cortés, 2011b; Lehmann, 2013, 2015; Mateos Cortés and Dietz, 2015; Olivera Rodríguez, 2017a, 2017b; Figueroa Saavedra et al., 2014).

The UVI has four regional sites in four diverse indigenous regions: the Huasteca, Grandes Montañas, Totonacapan and Las Selvas. At these sites, students can select flexible 'educational experiences' (in contrast with more common subject courses) and choose five different pathways within the licenciatura (or Bachelor's Degree) of Intercultural Management for Development: communication, law, languages, health and sustainability (UVI, 2007). The programme 'responds to an inter- or transdisciplinary, multimodal, flexible curriculum' (Dietz and Mateos Cortés, 2011a: 9) and is an officially recognized degree on a par with other degrees awarded by the Universidad Veracruzana.

Saavedra et al. (2014) carried out a study that analysed the final projects of recent graduates from the programme (from 2005 to 2012), and highlighted that many of the final projects were either partially or completely written and defended in one of the several indigenous languages of the region, meaning that indigenous languages were seen as a communicative vehicle (on a par with Spanish) for the generation and application of knowledge. This is a remarkable step in acknowledging that indigenous 
languages have a place within university systems and helps to provide a stronger sense of ownership and break the stigmatization and exclusion of indigenous peoples and languages in HE spaces. Furthermore, it represents how attitudes towards academic production in indigenous languages have shifted amongst both students, teachers and the wider academic community.

\section{Intercultural University Amawtay Wasi (Ecuador)}

In Ecuador, between 4 and 8 per cent of the population is indigenous, representing approximately 1 million people (Mato, 2014). According to a recent report from the Ministry of Higher Education, Science and Technology of Ecuador, less than 3 per cent of university students are indigenous (Rosales Picón, 2018).

The IUAW - meaning 'House of Wisdom' in the Kichwa language - opened in 2003, largely thanks to advocacy and support from the Confederation of Indigenous Nationalities of Ecuador (CONAIE) and the Scientific Institute of Indigenous Cultures (Krainer et al., 2017; Moctezuma Pérez, 2015). The university was the result of an extended period of consultation and debate between indigenous and non-indigenous teachers, researchers and professionals, both national and international, and represented a decolonial HE proposal unlike any that had existed before in Ecuador (Vargas Moreno, 2014). The intercultural curriculum of the IUAW operationalized interculturality within an academic and decolonial frame, with a particular focus on how knowledge is produced, who produces it and who legitimizes it. Thus, a 'dialogue of knowledges' emerged that was based on bestowing equal status, value, importance and legitimacy to indigenous knowledge (ibid.: 6). However, it was positioned as a private university given that it did not comply with the general conditions of public universities (Mato, 2014).

In 2010, a new HE law in Ecuador proposed a new quality control mechanism. The following year, the IUAW became the object of state scrutiny following an unfavourable evaluation from the Council for the Evaluation, Accreditation and Quality Assurance of Higher Education in Ecuador (CEAACES) (ibid.; Vargas Moreno, 2014). The challenges of being pressured to operate as if it were a private, for-profit university eventually became insurmountable, and by 2013 the IUAW had officially shut down (Martín-Díaz, 2017). The CONAIE considered this to be a violation of indigenous rights per the ILO Convention 169, and Mato (2016: 224) concludes that the university closed because the Ecuadorian government could no longer support a university 'whose institutional model and educational orientation did not correspond to those of the other public [and neoliberal] universities in the country'.

For many, the closure of the IUAW represented a setback not just for Ecuador's indigenous movement, but for other movements around the world that are struggling to ensure that indigenous cultures and knowledges are recognized as part of a national heritage and should be on equal terms with mestizo knowledge and cultures (Krainer et al., 2017; Martín-Díaz, 2017). As Erdösová (2015: 53) claims, IUAW's 'attributes were evaluated through an ideological prism of "academic excellence" based on modern Western criteria which have almost nothing in common with the indigenous concept of education'.

Martín-Díaz (2017) contended that the survival of institutions such as IUAW is dependent upon their ability to rally national and international support. Following its closure, staff, students and supporters mobilized and created their own proposal of a 'Pluriversity', Amawtay Wasi, that would effectively continue the fight to ensure their right to relevant education. Within six months of closing, they began publishing an online journal aimed at continuing and reformulating the project in some capacity, 
however diminished. The following was published in an open letter to the CEAACES regarding their decision to close the university:

today, the university [IUAW] has earned the acceptance and respect amongst those who are building the 'Southern epistemology', breaking with the geopolitics of knowledge that imposes 'the relevant' as something that always exists in other languages, is always created by certain actors and reaches us from certain places, none of which ever coincide with our languages, authors and places. (de Souza Silva, 2014: 24)

Krainer et al. (2017) suggest that IUAW has the potential to continue to shape the intercultural university project, regardless of whether or not it receives government recognition or support. In a recent development, a new HE law in Ecuador was approved in 2018 that proposed changing the university's status from a private university to a public, community-based university. Following this, the government and CONAIE signed an agreement that lays the groundwork for IUAW to officially reopen its doors in 2020 (Torres, 2019).

Drawing from these two cases, the final section provides an analysis of the potential for LLL to provide a renewed conceptual and policy framework that supports the development and improvement of intercultural universities across the LA region.

\section{How can lifelong learning support intercultural universities?}

In order to analyse whether LLL can help facilitate the mutual recognition necessary for intercultural dialogue (Llanes Ortiz, 2008) and the ways in which a more indigenized and decolonial framework could support existing and future intercultural universities, it is important to consider certain key points. First, there are context-specific dimensions that need to be taken into consideration when informing LLL and HE agendas (Preece, 2009; Torres 2019; Vargas, 2017; Mato, 2012, 2014, 2016). Second, the divide between Northern and Southern LLL perspectives (LLL for economic competitiveness and LLL for basic education, respectively) needs to be bridged through further research that challenges the converging global discourse creating an interplay with local discourses (Vargas, 2017). Finally, further studies that interrogate the extent to which different indigenous actors participate - on their own terms - in the construction, decisionmaking and governance of intercultural institutions would be necessary to continue the discussion on intercultural universities and provide the evidence needed for building a sustainable long-term strategy that significantly reduces the vulnerability of intercultural universities within increasingly neoliberal societies.

We chose to take a closer look at these two countries because we were interested in looking at why these two intercultural universities could have very different outcomes. The previous section detailed key aspects that both enabled and hindered the development of each university; however, we identified a key variable that arguably explains the different outcomes. We argue that the UVI remains a leading example of a nationally-recognized intercultural university model in Mexico owing to its more open approach to reconceptualizing what it means to be an intercultural institution (Mateos Cortés and Dietz, 2015) and its efforts of mutual transference of knowledge with community stakeholders (Dietz, 2012). In contrast, we posit that a lack of recognition of the independence and authority of the indigenous representatives in the institution's decision-making and governance eventually led to IUAW in Ecuador being unilaterally decommissioned by the state. 
The objectives of intercultural universities are similar to other HE institutions, with the key difference that social justice and revalidation of marginalized cultures are at the core of their conception. IUAW's case is a call for action to address issues related to the neoliberal dominance in HE in LA (Erdösová, 2015). Moreover, it raises the following question: how can intercultural universities survive when global forces evaluate their academic legitimacy and prestige based on modern Western criteria, such as indexes, rankings and numbers of publications? Some authors have criticized IGOs such as UNESCO, the UN and OECD for disregarding the unique background and realities of Southern countries, where the struggles in educational terms are not only focused on the development of skills for global competitiveness but also on provision, quality of education and intercultural education, among other aspects (Chomsky, 2011).

From the history of the concept, LLL was not proposed as an equivalent to a human capital perspective of education, but as a strategy to face European problems with competitiveness, demographic change and social inclusion (Commission of the European Communities, 2006). Discussing LLL exclusively in terms linked to a capitalist perspective of education would be to neglect the other social issues at the core of its conceptualization; issues relevant to supporting a debate on the diverse educational needs around the world and in local contexts. As a result, a holistic LLL perspective can be a powerful tool to strengthen intercultural universities and make them less vulnerable by recognizing how their aims, objectives and goals are linked to those of LLL and social justice. By formulating a respectful and pertinent LLL discourse that recognizes the intercultural necessities and opportunities of Southern contexts, these countries can address and challenge the tensions between their local educational needs and the global demands of the twenty-first century. On this, Preece (2009: 586) argues that 'Lifelong learning is actually a continuity with, rather than a departure from, tradition. That tradition was interrupted by the colonial endeavour and is a potential basis on which to build a broader social vision for LLL.'

The convergence of cultures, migration and colonialism make the educational needs in Southern countries heterogeneous and impossible to satisfy using a 'one size fits all' measure (Preece, 2009). The history of the region has perpetuated that 'double exclusion' of indigenous peoples from educational systems and maintained the status quo of Western-influenced elitist universities intact (Oyarzún et al., 2017; De Carvalho and Flórez-Flórez, 2014, Salinas de Dosch, 2012). In this context, intercultural universities can be seen as a mechanism for social justice and a way of 'indigenising the LLL agenda' (Preece, 2009: 595) that promotes a double inclusion for indigenous peoples.

The expansion of for-profit universities in the 1990s may have increased overall enrolment in $\mathrm{HE}$, but it did not satisfy quality standards or curricular pertinence to the different cultures in LA countries. Mato (2012) argues that universities in the region still have very little pertinence concerning social and cultural diversity of the countries, and as a consequence these universities are potentially missing out on key innovative social benefits. Cuenca (2015) calls this a mismatch between universities and cultural diversity. Similarly, Tubino (2007) states that discrimination in LA universities not only has an interpersonal dimension, but also an institutional dimension, given that these were built by and for the elite. He argues that traditional academia must change in order to become intercultural, and it is necessary to challenge the Western traditions on which these were built. Prior to discussions about the types of complex educational reforms that are needed for LA to compete on a global scale, there are neglected and contested issues with relation to what kind of education is appropriate and relevant.

It is in this context that protecting and supporting intercultural universities becomes an urgent social justice issue as they are a powerful source of decolonized 
education. One of the main challenges that intercultural universities face is how to operate according to the national and international HE standards that do not meet their characteristics and constantly challenge their validity. Furthermore, the indicators used by international agencies and governments often do not capture the learning process behind the assessments, and do not lead to a deeper understanding of distinct learning needs (Tikly, 2011). As a result, there is a need to question Western standards of quality HE and formulate appropriate approaches of quality education for different contexts. For example, Tikly (2010) and Tikly and Barrett (2011) have problematized how quality standards are used in postcolonial countries and designed a context-led framework for education quality. The authors' framework addresses social justice in education by combining inputs from the political environment, the institutional environment and community environment. It is in the interaction between these factors that quality education is understood. Additionally, their model is based on the active participation of disadvantaged groups in the decision-making of their educational programmes, a perspective that resonates with the statements in the ILO Convention 169.

Tikly (2010) also analyses quality education in its relation to both the human capital and human rights approaches, remaining critical with both perspectives and proposing an integrated approach. A similar vision of education is proposed for LLL in the Southern context. On one hand, the human capital approach understands education as a tool for economic growth and a mechanism of development and skill formation. On the other, the human rights approach is interested in the inherent right to access knowledge and to be recognized; in other words, to have 'rights to education, rights in education and rights through education' (Tikly, 2011: 6). In this sense, LA countries are in debt to their indigenous populations for neglecting their right to meaningful education for so long and considering indigenous knowledge on par with Western knowledge. Article 27 of ILO 169 recognizes the need for intercultural coexistence but fails to recognize cultural independence (Mato, 2014), forcing intercultural institutions to be measured against national standards without considering what those standards are and how out of context they might be. IUAW's case evidences unequal power relations (Preece, 2009) that fail to recognize indigenous representation within an intercultural university.

The Universidad Veracruzana offers an example of how it is possible to work collaboratively with institutions and governments and reformulate academic knowledge. The process by which this university opened the four regional UVI sites reflects how important it is to open traditional academia to changes; this project is sharing indigenous wisdom and innovative projects drawn from indigenous knowledge and is demonstrating its relevance by applying it to current challenges. The twenty-first century has brought on rapid change, and indigenous knowledge has the potential to provide innovative strategies and solutions that can benefit other regions of the world.

Raffe (2011) explains that when looking for solutions and best practices in other countries, the process involves understanding and analysing a country's own history and internal variables in order to design the most suitable solution for the context. Moreover, countries in the region can benefit from a critical analysis of the lessons learned from intercultural universities in Mexico and Ecuador. It will be interesting to see how the new IUAW develops in the following years and how Ecuador might have learned from previous mistakes.

Interculturality is opening the door for emerging decolonizing discourses within multicultural and multilingual contexts and has allowed for new critiques on how knowledge is valued, produced and disseminated (Kymlicka, 1995; Mignolo, 2000; 
Walsh, 2012). Furthermore, intercultural universities are challenging universalist (and predominantly European) notions and ideas of what a university is and should be: they seek to deconstruct and de-pattern 'traditional' notions of knowledge by incorporating 'novel learning processes of mutual transfers of knowledge' and including diverse actors and embedding a broad range of worldviews into the very core of their programmes (Dietz and Mateos Cortés, 2011b: 18). These universities are therefore positioned to act as a counter-hegemonic force in HE across the LA region. As demonstrated by the two cases in this article, the outlook for intercultural universities is uncertain, and yet it is one that offers a wide range of ideas, strategies and possibilities for the future.

\section{Notes on the contributors}

Lorena Sanchez Tyson is a doctoral candidate in the Department of Education, Practice and Society at UCL IOE. She holds a BA in English from the Universidad Autónoma de Tamaulipas (Mexico), and an MA in Lifelong Learning: Policy and Management. Her research focuses on adult literacy in multilingual and multicultural contexts; other interests include literacy, lifelong learning, unschooling, alternative learning, and indigenous and intercultural education.

Valerie Watson Vega has an MA in Lifelong Learning: Policy and Management from UCL IOE in the UK and the Universidad de Deusto in Spain, and a BA in Educational Psychology from Pontificia Universidad Católica del Perú, where she was a Psychology Faculty member. She has extensive experience in HE contexts and the development of training programmes in LA and the UK. Her research interests focus on the development of $\mathrm{HE}$ and social justice.

\section{References}

Ahuja, R., Campos, G., Muñoz, M. de L. and Crispin, M.L. (2004) Políticas y Fundamentos de la Educación Intercultural Bilingüe en México. Mexico City: Coordinación General de Educación Intercultural y Bilingüe.

Ananiadou, K. and Claro, M. (2009) 21st Century Skills and Competences for New Millennium Learners in OECD Countries. Paris: Organisation for Economic Co-operation and Development.

Arteaga, I. and Glewwe, P. (2014) Achievement Gap between Indigenous and Non-Indigenous Children in Peru: An analysis of Young Lives survey data (Working Paper 130). Oxford: Young Lives.

Baker, D.P. (2009) 'The educational transformation of work: Towards a new synthesis'. Journal of Education and Work, 22 (3), 163-91.

Balán, J. (2013) Latin America's New Knowledge Economy: Higher education, government, and international collaboration. New York: Institute of International Education.

Benavides, M., León, J., Haag, F. and Cueva, S. (2015) Expansión y diversificación de la educación superior universitaria, y su relación con la desigualdad y la segregación. Lima: Grupo de Análisis para el Desarrollo.

Bhambra, G.K., Gebrial, D. and Nişancıoğlu, K. (eds) (2018) Decolonising the University. London: Pluto Press.

Briones, C. (2008) 'Diversidad cultural e interculturalidad: ¿De qué estamos hablando?'. In García Vázquez, C. (ed.) Hegemonía e interculturalidad: Poblaciones originarias y migrantes. Buenos Aires: Prometeo Libros, 35-58.

Broch Hansen, K., Jepsen, K. and Leiva Jacquelin, P. (eds) (2017) The Indigenous World 2017. Copenhagen: International Work Group for Indigenous Affairs. Online. https://tinyurl.com/y2xmrgou (accessed 16 August 2019).

Chomsky, N. (2011) How the World Works. London: Hamish Hamilton.

Commission of the European Communities (2000) A Memorandum on Lifelong Learning (Commission Staff Working Paper). Brussels: Commission of the European Communities. Online. https://tinyurl.com/yy9goumj (accessed 14 August 2019). 
Commission of the European Communities (2006) Communication from the Commission - Adult Learning: It is never too late to learn. Brussels: Commission of the European Communities. Online. https://tinyurl.com/y5pe4ar4 (accessed 14 August 2019).

Cuenca, R. (ed.) (2015) La educación universitaria en el Perú: Democracia, expansión y desigualdades. Lima: Instituto de Estudios Peruanos.

De Carvalho, J.J. and Flórez-Flórez, J. (2014) 'The meeting of knowledges: A project for the decolonization of universities in Latin America'. Postcolonial Studies, 17 (2), 122-39.

Delors, J. (1996) Learning: the Treasure Within (Report to UNESCO of the International Commission on Education for the Twenty-first Century). Paris: UNESCO.

Denman, B.D. (2005) 'What is a university in the 21st century?'. Higher Education Management and Policy, 17 (2), 9-28.

Department of Economic and Social Affairs (2009) State of the World's Indigenous Peoples. New York: United Nations.

De Souza Silva, J. (2014) 'Carta de José de Souza Silva en solidaridad con la Universidad Amawtay Wasi'. Amawtay: Revista Digital de la Pluriversidad Amawtay Wasi, 1, 24-6.

De Wit, H., Jaramillo, I.C., Gacel-Ávila, J. and Knight, J. (eds) (2005) Higher Education in Latin America: The international dimension. Washington, DC: World Bank.

Diamantino, S. (2017) 'Correa, un neo-neoliberal'. Amawtay: Revista Digital de la Pluriversidad Amawtay Wasi, 4 (10), 5-6.

Dietz, G. (2012) 'Diversity regimes beyond multiculturalism? A reflexive ethnography of intercultural higher education in Veracruz, Mexico'. Latin American and Caribbean Ethnic Studies, 7 (2), 173-200.

Dietz, G. and Mateos Cortés, L.S. (2011a) Interculturalidad y Educación Intercultural en México: Un análisis de los discursos nacionales e internacionales en su impacto en los modelos educativos mexicanos. Mexico City: Secretaría de Educación Pública.

Dietz, G. and Mateos Cortés, L.S. (2011b) " Indigenising" or "interculturalising" Universities in Mexico? Towards an ethnography of diversity discourses and practices inside the Universidad Veracruzana Intercultural'. Learning and Teaching: The International Journal of Higher Education in the Social Sciences (LATISS), 4 (1), 4-21.

Dietz, G. and Mateos Cortés, L.S. (2016) 'Universidades Interculturales en México: balance crítico de la primera década'. Revista Mexicana de Investigación Educativa, 21 (70), 683-690. Online. https://doi.org/10.1016/j.quascirev.2005.07.009 (accessed 10 September 2019).

Erdösová, Z. (2015) 'Rethinking the borders in Latin America and the clash of social imaginaries: The impact of intercultural universities on indigenous autonomy'. Central European Journal of International and Security Studies, 9 (3), 42-57.

Faure, E., Herrera, F., Kaddoura, A.-R., Lopes, H., Petrovsky, A.V., Rahnema, M. and Champion Ward, F. (1972) Learning To Be: The world of education today and tomorrow. Paris: United Nations Educational, Scientific and Cultural Organization.

Ferreira, F.H.G., Messina, J., Rigolini, J., López-Calva, L.-F., Lugo, M.A. and Vakis, R. (2013) Economic Mobility and the Rise of the Latin American Middle Class. Washington, DC: World Bank.

Figueroa Saavedra, M., Alarcón Fuentes, D., Bernal Lorenzo, D. and Hernández Martínez, J.Á. (2014) 'La incorporación de las lenguas indígenas nacionales al desarrollo académico universitario: La experiencia de la Universidad Veracruzana'. Revista de la Educación Superior, 43 (171), 67-92.

Flores, F. and Díaz-Romero, P. (2008) 'Equidad en el acceso de los pueblos indígenas a la Educación Superior en el Perú: Avances, obstáculos y desafíos para la política pública'. Revista ISEES Inclusión Social y Equidad en la Educación Superior, 1, 87-102.

Gacel-Ávila, J. (2011) 'The impact of the Bologna Process on higher education in Latin America'. Revista de Universidad y Sociedad del Conocimiento, 8 (2), 285-96.

García, M.E. (2008) Desafíos de la interculturalidad: Educación, desarrollo e identidades indígenas en el Perú. Lima: Instituto de Estudios Peruanos.

Guilherme, M. and Dietz, G. (2017) 'Winds of the South: Intercultural university models for the 21st century'. Arts and Humanities in Higher Education, 16 (1), 7-16.

Hanemann, U. (2005) Literacy for Special Target Groups: Indigenous peoples. Paris: United Nations Educational, Scientific and Cultural Organization.

Hopenhayn, M. and Bello, A. (2001) Discriminación étnico-racial y xenofobia en América Latina y el Caribe. Santiago de Chile: CEPAL.

ILO (International Labour Organization) (1989) 'C169 - Indigenous and Tribal Peoples Convention, 1989 (No. 169)'. Online. https://tinyurl.com/y4hyymeu (accessed 16 August 2019). 
Krainer, A., Aguirre, D., Guerra, M. and Meiser, A. (2017) 'Educación superior intercultural y diálogo de saberes: El caso de la Amawtay Wasi en Ecuador'. Revista de la Educación Superior, 46 (184), 55-76.

Kymlicka, W. (1995) Multicultural Citizenship: A liberal theory of minority rights. Oxford: Clarendon Press.

Lauder, H. (2011) 'Education, economic globalisation and national qualifications frameworks'. Journal of Education and Work, 24 (3-4), 213-21.

Lehmann, D. (2013) 'Intercultural universities in Mexico: Identity and inclusion'. Journal of Latin American Studies, 45 (4), 779-811.

Lehmann, D. (2015) 'Convergencias y divergencias en la educación superior intercultural en México'. Revista Mexicana de Ciencias Políticas y Sociales, 60 (223), 133-70.

Llanes Ortiz, G. de J. (2008) 'Interculturalización fallida: Desarrollismo, neoindigenismo y universidad intercultural en Yucatán, México'. Trace, 53, 49-63.

Martín-Díaz, E. (2017) 'Are universities ready for interculturality? The case of the Intercultural University "Amawtay Wasi" (Ecuador)'. Journal of Latin American Cultural Studies, 26 (1), 73-90.

Martins, C.B. (2013) 'Reconfiguring higher education in Brazil: The participation of private institutions'. Análise Social, 48 (208), 622-58.

Mateos Cortés, L.S. and Dietz, G. (2015) 'How intercultural is an "intercultural university"? Some lessons from Veracruz, Mexico'. Revista Lusófona de Educação, 31, 125-43.

Mato, D. (ed.) (2012) Educación Superior y Pueblos Indígenas y Afrodescendientes en América Latina: Normas, políticas y prácticas. Caracas: IESALC-UNESCO.

Mato, D. (2014) 'Universidades Indígenas en América Latina: Experiencias, logros, problemas, conflictos y desafíos'. Revista ISEES: Inclusión Social y Equidad en la Educación Superior, $14,17-45$.

Mato, D. (2016) 'Indigenous people in Latin America: Movements and universities: Achievements, challenges, and intercultural conflicts'. Journal of Intercultural Studies, 37 (3), 211-33.

Mignolo, W.D. (2000) Local Histories/Global Designs: Coloniality, subaltern knowledges, and border thinking. Princeton: Princeton University Press.

Moctezuma Pérez, N. (2015) 'La Universidad Intercultural Amawtay Wasi: Una experiencia políticoeducativa'. CISMA: Revista del Centro Telúrico de Investigaciones Teóricas, 3 (6), 1-23.

Nuissl, E. and Przybylska, E. (2016) 'Lifelong learning: History and the present state of the politicallyeducational concept'. Studia Paedagogica Ignatiana, 19 (4), 33-48.

OECD (Organisation for Economic Co-operation and Development) (1996) Lifelong Learning for All: Meeting of the Education Committee at Ministerial Level, 16-17 January 1996. Paris: Organisation for Economic Co-operation and Development.

Olivera Rodríguez, I. (2017a) 'Las potencialidades del proyecto educativo de la Universidad Veracruzana Intercultural: Una crítica al desarrollo desde la noción del Buen vivir'. Revista de la Educación Superior, 46 (181), 19-35.

Olivera Rodríguez, I. (2017b) 'Nuevos escenarios, nuevas propuestas, otras actoras: Licenciadas indígenas y la Universidad Veracruzana Intercultural'. Anthropologica, 35 (39), 75-98.

Oyarzún, J. de D., Perales Franco, C. and McCowan, T. (2017) 'Indigenous higher education in Mexico and Brazil: Between redistribution and recognition'. Compare: A Journal of Comparative and International Education, 47 (6), 852-71.

Portnoi, L.M. (2016) Policy Borrowing and Reform in Education: Globalized processes and local contexts. New York: Palgrave Macmillan.

Preece, J. (2009) 'Lifelong learning and development: A perspective from the "South"'. Compare: A Journal of Comparative and International Education, 39 (5), 585-99.

Preece, J. (2011) Lifelong Learning and Development: A Southern perspective. London: Continuum.

Raffe, D. (2011) Policy Borrowing or Policy Learning? How (not) to improve education systems (CES Briefing 57). Edinburgh: Centre for Educational Sociology. Online. www.ces.ed.ac.uk/PDF\%20Files/Brief057.pdf (accessed 4 June 2017).

Raffe, D. and Spours, K. (eds) (2007) Policy-Making and Policy-Learning in 14-19 Education (Bedford Way Papers 26). London: Institute of Education.

Robertson, S.L. (2008) 'The Bologna Process goes global: A model, market, mobility, brain power or state building strategy?'. Paper presented at the Associação Nacional de Pós-Graduação e Pesquisa em Educação (ANPEd) Annual Conference, Caxambu, Brazil, 19-22 October 2008.

Robinson-Pant, A. (2001) 'Development as discourse: What relevance to education?'. Compare: A Journal of Comparative and International Education, 31 (3), 311-28.

Rodríguez Ponce, E. (2012) 'La educación superior en Chile y el rol del mercado: ¿Culpable o inocente?'. Ingeniare: Revista chilena de ingeniería, 20 (1), 126-35. 
Rosales Picón, B.P. (2018) Boletín analítico de educación superior, ciencia, tecnología, innovación y saberes ancestrales. Quito: SENESCYT.

Salinas de Dosch, A.L. (2012) 'Understanding Latin America indigenous movements: From marginalisation to self-determination and autonomy?'. Paper presented at the 3rd International Seminar and Workshop on Latin American and Asian Studies (LASA III), Institute of Occidental Studies, Universiti Kebangsaan Malaysia, 17-18 October 2012. Online. https://tinyurl.com/yxz8j84x (accessed 16 August 2019).

Sanchez Tyson, L. (2017) '"I Read and Write in My Own Language": A case study of a non-formal indigenous language literacy programme in Mexico'. Unpublished thesis, UCL Institute of Education.

Schmelkes, S. (2009) 'Intercultural universities in Mexico: Progress and difficulties'. Intercultural Education, 20 (1), 5-17.

Schmelkes, S. (2011) 'Adult education and indigenous peoples in Latin America'. International Review of Education, 57 (1-2), 89-105.

Schuetze, H.G. (2005) Financing Lifelong Learning: Potential of and problems with individual learning accounts in three countries. New York: National Center for the Study of Privatization in Education.

Steiner-Khamsi, G. (2016) 'New directions in policy borrowing research'. Asia Pacific Education Review, 17 (3), 381-90.

Tikly, L. (2010) A Framework for Education Quality (EdQual Policy Brief 10). Bristol: EdQual.

Tikly, L. (2011) 'Towards a framework for researching the quality of education in low-income countries'. Comparative Education, 47 (1), 1-23.

Tikly, L. and Barrett, A.M. (2011) 'Social justice, capabilities and the quality of education in low income countries'. International Journal of Educational Development, 31 (1), 3-14.

Torres, C.A. and Schugurensky, D. (2002) 'The political economy of higher education in the era of neoliberal globalization: Latin America in comparative perspective'. Higher Education, 43 (4), 429-55.

Torres, R.M. (2004) Lifelong Learning in the South: Critical issues and opportunities for adult education. Stockholm: Swedish International Development Cooperation Agency.

Torres, R.M. (2019) 'La Universidad Intercultural Amawtay Wasi (Ecuador)'. Online. https://tinyurl.com/yxqew9pf (accessed 16 August 2019).

Tubino, F. (2007) 'Las ambivalencias de las acciones afirmativas'. In Ansion, J. and Tubino, F. (eds) Educar en ciudadanía intercultural: Experiencias y retos en la formación de estudiantes universitarios indígenas. Lima: Fondo Editorial de la Pontificia Universidad Católica del Perú, 91-110.

UNESCO (United Nations Educational, Scientific and Cultural Organization) (2015) Rethinking Education: Towards a global common good? Paris: UNESCO Publishing.

UVI (Universidad Veracruzana Intercultural) (2007) Licenciatura en Gestión Intercultural para el Desarrollo: Programa multimodal de formación integral. Xalapa: Universidad Veracruzana Intercultural.

Vargas, C. (2017) Lifelong Learning from a Social Justice Perspective (Education Research and Foresight Working Paper 21). Paris: United Nations Educational, Scientific and Cultural Organization.

Vargas Moreno, P. (2014) 'Educación Superior Intercultural en disputa: Trayectorias de la Universidad Intercultural Amawtay Wasi'. Polis, 38, 1-26. Online. https://journals.openedition.org/polis/10136 (accessed 14 August 2019).

Vásquez Huamán, E., Chumpitaz, A. and Jara, C. (2009) Niñez Indígena y Educación Intercultural Bilingüe en el Perú: Estadísticas recientes, preguntas (i)resueltas y tareas pendientes. Lima: Care Perú.

Walsh, C. (2012) '"Other" knowledges, "other" critiques: Reflections on the politics and practices of philosophy and decoloniality in the "other" America'. Transmodernity: Journal of Peripheral Cultural Production of the Luso-Hispanic World, 1 (3), 11-27.

Watson Vega, V. (2017) 'Reforming and Expanding Higher Education: The Latin American predicament'. Unpublished thesis, UCL Institute of Education. 